\title{
71. SPINELS IN LEG 37 BASALTS AND PERIDOTITES: PHASE CHEMISTRY AND ZONING
}

\author{
Haraldur Sigurdsson, Graduate School of Oceanography, University of R hode Island, Kingston, Rhode Island
}

\section{INTRODUCTION}

Spinels are present as rare inclusions or microphenocrysts in 14 of the 34 samples of Leg 37 core examined. They are common microphenocrysts in the picrites and olivine-rich lavas (MgO $11 \%-14 \%)$ of Hole 332B (analyses $5,10,11,12$, and 15 of Table 1) where they form 500 to $1200 \mathrm{ppm}$ of the mode. Spinels are present but less abundant in the olivine and plagioclase glomerophyric basalts (analyses 6,7 , and 8 of Table 1) and in the low-MgO (6\%-7\%) plagioclase-rich basalts of Hole 332B (analyses 13 and 14 of Table 1), forming 100 to $500 \mathrm{ppm}$ of the mode, and in the sparsely olivinephyric basalt of Hole 332B (analysis 9, Table 1).

Spinels typically occur as small octahedra in olivine phenocrysts or, more rarely, in plagioclase. They range in diameter from 10 to $500 \mu \mathrm{m}$, with a mean diameter of $60 \mu \mathrm{m}$. Spinels typically form $50-100 \mathrm{ppm}$ of the mode but may range up to $1200 \mathrm{ppm}$ of the mode in the picrites. Most grains are translucent reddish-brown in color, grading to yellow-brown or amber for Al-rich varieties. The transluscence of spinels decreases with increasing iron content and the iron-rich spinels of the peridotite samples $\left[\mathrm{Mg} /\left(\mathrm{Mg}+\mathrm{Fe}^{2+}\right)\right.$ less than 0.6$]$ are opaque, in common with most chromites. The compositional ranges of spinels and associated olivine and plagioclase phenocrysts are given in Table 2. The results of a microprobe study of spinels in Leg 37 basalts are reported here, together with analyses of spinels forming abundant inclusions in olivines and clinopryoxenes of the serpentinized peridotite at Site 334 and of rare spinels in the sparsely phyric basalts at Site 335 .

\section{RESULTS}

One hundred analyses of spinels in Leg 37 basalt and peridotite were carried out in this study using an automated 4-spectrometer ARL-EMX SM electron probe and standard correction procedures (Bence and Albee, 1968). Seven elements were analyzed in all cases ( $\mathrm{Si}, \mathrm{Al}, \mathrm{Cr}, \mathrm{Ti}, \mathrm{Fe}, \mathrm{Mn}$, and $\mathrm{Mg}$ ), but $\mathrm{Si}$ was rarely detected. The analyses were recast in structural formulas on the basis of 32 oxygens. Total $\mathrm{Fe}$ was partitioned between $\mathrm{A}$ and $\mathrm{B}$ sites as $\mathrm{Fe}^{2+}$ and $\mathrm{Fe}^{3+}$ in the proportions required for stoichiometry (Finger, 1972), yielding an estimation of the amount of ferric iron in the spinels.

Representative microprobe analyses of Leg 37 spinels are given in Table 3 , and all analyses are plotted in Figure $1 \mathrm{a}, \mathrm{b}$. The results of Leg 37 are closely comparable with data collected on spinels in pillow basalts dredged from the MAR (Mid-Atlantic Ridge) between $29^{\circ} \mathrm{N}$ and $40^{\circ} \mathrm{N}$ (Sigurdsson and Schilling, in preparation) whose compositional fields are also shown in Figure 1. In view of the virtual absence of the magnetite $\left(\mathrm{FeFe}_{2} \mathrm{O}_{4}\right)$ and ulvospinel $\left(\mathrm{Fe}_{2} \mathrm{TiO}_{4}\right)$ molecules in these spinels, their compositions can be accurately represented in terms of $\mathrm{Cr} /(\mathrm{Cr}+\mathrm{Al})$ and $\mathrm{Mg} /\left(\mathrm{Mg}+\mathrm{Fe}^{2+}\right)($ Table 3$)$.

Members of the spinel-chromite series in basaltic rocks are generally divided into magnesiochromites $\left(\mathrm{Mg}>\mathrm{Fe}^{2+}, \mathrm{Cr}>\mathrm{Al}\right)$ and chromian spinels $\left(\mathrm{Mg}>\mathrm{Fe}^{2+}\right.$, $\mathrm{Al}>\mathrm{Cr}$ ). The majority of spinels in MAR basaltic rocks, however, form a coherent compositional group, straddling the boundary of these two classes $(\mathrm{Cr} / \mathrm{Cr}+$ Al) $=0.5)$, and will be referred to as magnesiochromites in the following discussion. It is nevertheless emphasized that this artificial classification is for descriptive purposes alone, since a solidsolution series exists for this range of the spinel series, as evidenced by the extensive zoning in some Leg 37 spinels (Figures 1 and 2).

It is evident from Figure 1 that substitution between $\mathrm{Cr}$ and $\mathrm{Al}$ in the octahedral site is the dominant feature of the phase chemistry of MAR spinels, accompanied by minor $\mathrm{Mg}-\mathrm{Fe}^{2+}$ substitution. The spinels contain only minor amounts of $\mathrm{Ti}$ and $\mathrm{Mn}$ and do not show enrichment of these elements except in iron-rich rims.

The Leg 37 magnesiochromites closely resemble spinels in alpine-type peridotites (Irvine, 1967) Loney et al., 1971; Dickey and Yoder, 1972). They differ from chromites of stratiform intrusions such as the Stillwater (Jackson, 1969), in having higher $\mathrm{Mg} /\left(\mathrm{Mg}+\mathrm{Fe}^{2+}\right)$ and generally lower $\mathrm{Cr} /(\mathrm{Cr}+\mathrm{Al})$ ratios than the latter. The highly zoned chromian spinels in the plagioclase-phyric lavas of Leg 37 (analysis 10 in Table 1) are the most aluminous spinels hitherto reported from basalts. They are somewhat more aluminous than comparable chromian spinels from MAR picrites (Sigurdsson and Schilling, in preparation) and approximate closely the composition of chromian spinels in lherzolite nodules believed to be of upper mantle origin (O'Hara et al., 1971; Littlejohn and Greenwood, 1974; Aoki and Prinz, 1974).

\section{ZONING}

Spinels from the holocrystalline basalts of Leg 37 show extensive compositional zoning, in contrast to the largely homogeneous liquidus spinels in variolitic and glassy basalts from the MAR (Sigurdsson and Schilling, in preparation). Three types of zoning have been observed: most magnesiochromites show "normal" zoning, involving decrease in $\mathrm{Cr} /(\mathrm{Cr}+\mathrm{Al})$ from core to rim, with little or no change in the $\mathrm{Mg} /\left(\mathrm{Mg}+\mathrm{Fe}^{2+}\right)$ ratio (I in Figure 1). This spinel growth, involving substitution of $\mathrm{Al}$ for $\mathrm{Cr}$, occurs during a stage intermediate between intratelluric and groundmass 
TABLE

Microprobe Analyses of Volcanic Glasses and Fused Beads of Spinel-Bearing Rocks and Other Basalts from Leg 37

\begin{tabular}{|c|c|c|c|c|c|c|c|c|c|c|c|c|c|c|c|c|c|c|}
\hline & 1 & 2 & 3 & 4 & 5 & 6 & 7 & 8 & 9 & 10 & 11 & 12 & 13 & 14 & 15 & 16 & 17. & 18 \\
\hline $\mathrm{SiO}_{2}$ & 50.7 & 50.7 & 51.8 & 50.3 & 49.3 & 49.3 & 50.0 & 49.7 & 48.9 & 50.1 & 47.8 & 46.0 & 49.9 & 49.4 & 50.9 & 50.3 & 49.8 & 49.8 \\
\hline $\mathrm{Al}_{2} \mathrm{O}_{3}$ & 13.8 & 13.2 & 14.8 & 14.0 & 15.3 & 17.0 & 16.4 & 16.5 & 17.0 & 15.3 & 16.2 & 13.9 & 18.2 & 19.0 & 16.2 & 14.3 & 15.0 & 16.0 \\
\hline $\mathrm{Fe}_{2} \mathrm{O}_{3}$ & 1.5 & 1.5 & 1.5 & 1.5 & 1.5 & 1.5 & 1.5 & 1.5 & 1.5 & 1.5 & 1.5 & 1.5 & 1.5 & 1.5 & 1.5 & 1.5 & 1.5 & 1.5 \\
\hline $\mathrm{FeO}$ & 8.9 & 9.3 & 8.3 & 7.8 & 7.4 & 7.1 & 7.5 & 8.2 & 8.2 & 5.7 & 7.2 & 8.5 & 5.6 & 5.1 & 5.3 & 8.6 & 8.2 & 8.0 \\
\hline $\mathrm{MgO}$ & 7.7 & 7.1 & 7.3 & 8.4 & 11.2 & 9.2 & 8.9 & 8.8 & 7.9 & 12.3 & 11.4 & 13.8 & 6.8 & 6.7 & 12.4 & 7.8 & 8.1 & 7.9 \\
\hline $\mathrm{CaO}$ & 12.6 & 11.8 & 12.4 & 12.8 & 11.9 & 12.3 & 11.5 & 11.8 & 13.5 & 12.0 & 11.3 & 11.5 & 14.9 & 15.0 & 11.7 & 12.2 & 11.6 & 11.5 \\
\hline $\mathrm{Na}_{2} \mathrm{O}$ & 2.20 & 2.30 & 2.19 & 2.02 & 2.08 & 2.20 & 2.44 & 2.32 & 2.30 & 2.10 & 2.11 & 1.83 & 2.10 & 1.89 & 2.01 & 2.30 & 2.48 & 2.51 \\
\hline $\mathrm{K}_{2} \mathrm{O}$ & 0.20 & 0.21 & 0.31 & 0.15 & 0.14 & 0.11 & 0.15 & 0.16 & 0.18 & 0.24 & 0.14 & 0.20 & 0.17 & 0.14 & 0.08 & 0.22 & 0.19 & 0.20 \\
\hline $\mathrm{TiO}_{2}$ & 1.15 & 1.16 & 1.13 & 0.96 & 0.72 & 0.80 & 0.84 & 0.81 & 0.89 & 0.66 & 0.60 & 0.59 & 0.73 & 0.59 & 0.69 & 1.18 & 1.22 & 1.27 \\
\hline $\mathrm{MnO}$ & 0.22 & 0.19 & 0.21 & 0.23 & 0.15 & 0.15 & 0.17 & 0.17 & 0.21 & 0.16 & 0.19 & 0.18 & 0.14 & 0.16 & 0.16 & 0.21 & 0.20 & 0.18 \\
\hline $\mathrm{Cr}_{2} \mathrm{O}_{3}$ & 0.04 & 0.02 & 0.02 & 0.05 & 0.11 & 0.09 & 0.09 & 0.09 & 0.07 & 0.17 & 0.14 & 0.23 & 0.06 & 0.08 & 0.12 & 0.08 & 0.06 & 0.06 \\
\hline Total & 99.0 & 97.5 & 99.9 & 98.2 & 99.8 & 99.8 & 99.5 & 100.01 & 100.7 & 100.3 & 98.5 & 98.2 & 100.1 & 99.6 & 101.1 & 98.7 & 98.4 & 99.0 \\
\hline
\end{tabular}

Note: $1=332 \mathrm{~A}-7-1,5-10 \mathrm{~cm}$, volcanic glass $2=332 \mathrm{~A}-8-1,47 \mathrm{~cm}$, volcanic glass: $3=332 \mathrm{~A}-8-2,2-15 \mathrm{~cm}$, basalt $; 4=332 \mathrm{~A}-22-1,76 \mathrm{~cm}$, volcanic glass; $5=332 \mathrm{~B}-20-2,34-36 \mathrm{~cm}$, picritic basalt; $6=332 \mathrm{~B}-22-1,97-100 \mathrm{~cm}$, glomerophyric basalt; $7=332 \mathrm{~B}-22-4,22-24 \mathrm{~cm}$, glomerophyric basalt; $8=332 \mathrm{~B}-23-1,100-102 \mathrm{~cm}$, glomerophyric basalt; $9=332 \mathrm{~B}-$ $25-4,51-53 \mathrm{~cm}$, sparsely phyric basalt; $10=332 \mathrm{~B}-29-1,69-72 \mathrm{~cm}$. picritic basalt: $11=332 \mathrm{~B}-29-2,9-12 \mathrm{~cm}$, picritic basalt; $12=332 \mathrm{~B}-35-2,62-65 \mathrm{~cm}$, picritic basalt; $13=332 \mathrm{~B}-36-2,3-12 \mathrm{~cm}$, plagioclase-phyric basalt: $14=332 \mathrm{~B}-36-2,81-83 \mathrm{~cm}$, plagioclase-phyric basalt; $15=332 \mathrm{~B}-37-3,11-13 \mathrm{~cm}$, picritic basalt; $16=335-6-1,47-49 \mathrm{~cm}$, volcanic glass; $17=335-8-3,98-101 \mathrm{~cm}$, volcanic glass; $18=335-8-3,98-101 \mathrm{~cm}$, volcanic glass. Each analysis is the average of three microprobe analyses. Fused beads were prepared by melting $0.5-\mathrm{g}$ rock powder in graphite crucibles in platinum-wound quench furnace at $1350^{\circ} \mathrm{C}$ for 30 min. Total iron was analyzed by microprobe, but $1.5 \%$ has been assumed to be $\mathrm{Fe}_{2} \mathrm{O}_{3}$ for comparative purposes.

TABLE 2

Compositional Ranges of Phenocrysts and Spinels in Leg 37 Rocks

\begin{tabular}{|c|c|c|c|c|c|c|}
\hline \multirow{2}{*}{$\begin{array}{c}\text { Sample } \\
\text { (Interval in } \mathrm{cm} \text { ) }\end{array}$} & \multirow[b]{2}{*}{ Rock Type } & \multirow{2}{*}{$\begin{array}{l}\text { Olivine } \\
\text { Fo mol \% }\end{array}$} & \multirow{2}{*}{$\begin{array}{l}\text { Plagioclase } \\
\text { An mol \% }\end{array}$} & \multicolumn{2}{|c|}{ Spinel } & \multirow{2}{*}{$\begin{array}{c}\text { Rock } \\
\mathrm{FeO}^{* /} \\
\left(\mathrm{Fe} 0^{*}+\mathrm{Mg} 0\right)\end{array}$} \\
\hline & & & & $\mathrm{Mg} /\left(\mathrm{Mg}+\mathrm{Fe}^{2+}\right)$ & $\overline{\mathrm{Cr} /(\mathrm{Cr}+\mathrm{A} 1)}$ & \\
\hline $332 \mathrm{~B}-20-2,34-36$ & Picritic basalt & $86.5-87.9$ & $70.2-71.6$ & $0.67-0.69$ & $0.51-0.54$ & 0.44 \\
\hline $332 \mathrm{~B}-22-1,97-100$ & Glomerophyric basalt & $84.9-85.8$ & 77.1 & $0.66-0.67$ & $0.44-0.47$ & 0.48 \\
\hline $332 \mathrm{~B}-22-4,22-24$ & Glomerophyric basalt & $84.8-85.0$ & $75.3-83.8$ & $0.63-0.64$ & $0.45-0.46$ & 0.50 \\
\hline $332 \mathrm{~B}-23-1,100-102$ & Glomerophyric basalt & $84.2-85.0$ & $74.8-83.8$ & 0.62 & 0.44 & 0.52 \\
\hline $332 \mathrm{~B}-25-4,51-53$ & Sparsely phyric basalt & $85.5-85.7$ & & $0.64-0.68$ & $0.42-0.45$ & 0.55 \\
\hline $332 \mathrm{~B}-29-1,69-72$ & Picritic basalt & $87.4-89.7$ & & $0.69-0.71$ & $0.47-0.48$ & 0.36 \\
\hline $332 \mathrm{~B}-29-2,9-12$ & Picritic basalt & $87.7-88.1$ & & $0.70-0.73$ & $0.56-0.59$ & 0.43 \\
\hline $332 \mathrm{~B}-35-2,62-65$ & Picritic basalt & $89.4-89.6$ & & $0.70-0.73$ & $0.52-0.55$ & 0.42 \\
\hline $332 \mathrm{~B}-36-2,3-12$ & Plagioclase phyric basalt & Relics & & $0.72-0.78$ & $0.35-0.42$ & 0.51 \\
\hline $332 \mathrm{~B}-36-2,81-83$ & Plagioclase phyric basalt & Relics & $78.7-89.7$ & $0.70-0.83$ & $0.17-0.44$ & 0.49 \\
\hline $332 \mathrm{~B}-37-3,11-13$ & Picritic basalt & $87.7-88.1$ & & $0.69-0.70$ & $0.50-0.58$ & 0.35 \\
\hline $334-22-2,52-55$ & Peridotite & $87.7-88.0$ & & $0.54-0.59$ & $0.56-0.57$ & \\
\hline $334-22-2,85-87$ & Peridotite & $88.4-88.7$ & & $0.52-0.57$ & $0.50-0.59$ & \\
\hline $335-8-2,94-96$ & Sparsely phyric basalt & $85.1-85.7$ & $72.1-79.2$ & $0.68-0.75$ & $0.47-0.48$ & \\
\hline
\end{tabular}

crystallization, just prior to eruption. Zoning of this type is most probably a reflection of $\mathrm{Cr}$ fractionation from melt into olivines during ascent of magma, resulting in increasing substitution of abundant $\mathrm{Al}$ for $\mathrm{Cr}$ in the octahedral spinel site, in response to decreasing $\mathrm{Cr}$ content of the melt. This zoning is not reflected by concentrations of the other elements analyzed in the spinels, nor does it appear to affect the ratio $\mathrm{Fe}^{3+} /\left(\mathrm{Fe}^{3+}\right.$ $+\mathrm{Cr}+\mathrm{Al}$ ), suggesting that variations in oxygen fugacity are not involved.

A second type of zoning involves iron enrichment, as manifested by decreasing $\mathrm{Mg} /\left(\mathrm{Mg}+\mathrm{Fe}^{2+}\right)$ and increasing $\mathrm{Fe}^{3+} /\left(\mathrm{Fe}^{3+}+\mathrm{Cr}+\mathrm{Al}\right)$ ratios from magnesiochromite cores to narrow rims trending to chromite composition (II in Figure 1). This "chromite" zoning is attributed to $\mathrm{Fe} / \mathrm{Mg}$ fractionation of the melt (decreasing $\mathrm{Mg} / \mathrm{Mg}+\mathrm{Fe}^{2+}$ ) along with posteruptive increase in $\mathrm{Ti}$ and Mn. These "chromite" zones are compositionally closer to spinels in the Leg 37 peridotites than any other basaltic spinels from the MAR.

Zoning of the third type, "reverse" zoning, has only been observed in chromian spinels from the plagioclase-rich basalts in the lower part of Hole 332B
(III in Figure 1). Chromian spinel cores (amber) are zoned to magnesiochromite rims (brown), with increase in $\mathrm{Cr} /(\mathrm{Cr}+\mathrm{Al})$ from 0.2 to 0.4 and decrease in $\mathrm{Mg} /\left(\mathrm{Mg}+\mathrm{Fe}^{2+}\right)$ from 0.82 to 0.72 , accompanied by minor increase in $\mathrm{Ti}$ and $\mathrm{Mn}$ from core to rim. Spinels showing extreme "reverse" zoning of this type occur in Sample 332B-36-2, 81-83 cm and two examples are shown in photomicrographs in Figure 2. They are characteristically euhedral grains, 60 to $100 \mu \mathrm{m}$ in diameter and generally occur attached to plagioclase phenocrysts of $A_{83-90}$ composition or enclosed in pseudomorphs after olivine. A compositional traverse from core to rim of a chromian spinel, illustrated in Figure 2b, is plotted in Figure 3. The chromian spinelbearing lavas from Leg 37 are plagioclase-rich and differentiated rocks, enriched in $\mathrm{Al}_{2} \mathrm{O}_{3}$ and $\mathrm{CaO}$ and depleted in $\mathrm{MgO}, \mathrm{FeO}, \mathrm{TiO}_{2}$, and $\mathrm{Cr}_{2} \mathrm{O}_{3}$ (analyses 13 and 14 in Table 1), most probably due to crystal accumulation in a shallow reservoir. Rare chromian spinel cores in these lavas most likely represent cognate xenocrysts which have begun to crystallize at high pressure from a picritic parental magma. High-Al chromian spinel cores are, however, rare in these lavas, 
TABLE 3

Representative Microprobe Analyses of Spinels in Leg 37 Rocks

\begin{tabular}{|c|c|c|c|c|c|c|c|c|c|c|c|c|c|}
\hline & 1 & 2 & 3 & 4 & 5 & 6 & 7 & 8 & 9 & 10 & 11 & 12 & 13 \\
\hline $\mathrm{Al}_{2} \mathrm{O}_{3}$ & 29.1 & 31.0 & 28.2 & 22.2 & 29.7 & 21.4 & 29.0 & 35.7 & 49.2 & 35.0 & 22.5 & 26.5 & 29.0 \\
\hline $\mathrm{Cr}_{2} \mathrm{O}_{3}$ & 34.5 & 33.8 & 38.0 & 45.8 & 35.1 & 44.8 & 36.9 & 32.2 & 15.4 & 30.8 & 42.1 & 39.6 & 38.6 \\
\hline $\mathrm{TiO}_{2}$ & 0.53 & 0.40 & 0.30 & 0.42 & 0.32 & 0.40 & 0.33 & 0.16 & 0.13 & 0.17 & 0.54 & 0.16 & 0.22 \\
\hline $\mathrm{Fe}_{2} \mathrm{O}_{3}$ & 7.9 & 6.1 & 5.6 & 5.5 & 6.9 & 5.7 & 5.9 & 4.3 & 4.8 & 5.2 & 6.8 & 4.8 & 4.9 \\
\hline $\mathrm{FeO}$ & 13.2 & 13.2 & 11.6 & 11.7 & 13.1 & 11.7 & 12.2 & 10.2 & 8.7 & 9.6 & 17.2 & 16.8 & 10.7 \\
\hline $\mathrm{MgO}$ & 15.3 & 15.0 & 16.2 & 15.7 & 15.1 & 15.2 & 15.8 & 18.0 & 19.9 & 18.0 & 12.1 & 12.7 & 16.9 \\
\hline \multirow[t]{2}{*}{$\mathrm{MnO}$} & 0.22 & 0.22 & 0.17 & 0.22 & 0.21 & 0.21 & 0.21 & 0.16 & 0.03 & 0.13 & 0.28 & 0.26 & 0.23 \\
\hline & 100.8 & 99.7 & 100.0 & 101.5 & 100.4 & 99.4 & 100.3 & 100.7 & 98.2 & 98.9 & 101.5 & 100.8 & 100.6 \\
\hline $\mathrm{Al}$ & 8.083 & 8.580 & 7.865 & 6.259 & 8.215 & 6.194 & 8.040 & 9.492 & 12.554 & 9.478 & 6.485 & 7.541 & 7.987 \\
\hline $\mathrm{Cr}$ & 6.430 & 6.276 & 7.087 & 8.674 & 6.504 & 8.683 & 6.587 & 5.748 & 2.635 & 5.594 & 8.155 & 7.555 & 7.116 \\
\hline $\mathrm{Ti}$ & 0.094 & 0.070 & 0.053 & 0.074 & 0.055 & 0.072 & 0.058 & 0.026 & 0.022 & 0.029 & 0.101 & 0.029 & 0.038 \\
\hline $\mathrm{Fe}^{3+}$ & 1.394 & 1.074 & 0.995 & 0.993 & 1.226 & 1.050 & 1.046 & 0.734 & 0.789 & 0.899 & 1.259 & 0.875 & 0858 \\
\hline $\mathrm{Fe}^{2+}$ & 2.590 & 2.588 & 2.276 & 2.331 & 2.564 & 2.406 & 2.382 & 1.914 & 1.578 & 1.834 & 3.524 & 3.382 & 2.074 \\
\hline $\mathrm{Mg}$ & 5.364 & 5.268 & 5.686 & 5.623 & 5.258 & 5.551 & 5.518 & 6.053 & 6.418 & 6.142 & 4.416 & 4.565 & 5.878 \\
\hline $\mathrm{Mn}$ & 0.046 & 0.043 & 0.034 & 0.046 & 0.041 & 0.043 & 0.041 & 0.031 & 0.005 & 0.026 & 0.058 & 0.053 & 0.046 \\
\hline $\mathrm{Mg} /\left(\mathrm{Mg}+\mathrm{Fe}^{2+}\right)$ & 0.674 & 0.671 & 0.714 & 0.707 & 0.672 & 0.698 & 0.699 & 0.760 & 0.803 & 0.770 & 0.556 & 0.574 & 0.739 \\
\hline $\mathrm{Cr} /(\mathrm{Cr}+\mathrm{Al})$ & 0.443 & 0.423 & 0.474 & 0.581 & 0.442 & 0.584 & 0.460 & 0.377 & 0.174 & 0.371 & 0.557 & 0.501 & 0.471 \\
\hline $\mathrm{Fe}^{3+} /\left(\mathrm{Fe}^{3+}+\mathrm{Cr}_{\mathrm{r}}+\mathrm{Al}\right)$ & 0.088 & 0.067 & 0.062 & 0.062 & 0.077 & 0.066 & 0.066 & 0.046 & 0.049 & 0.056 & 0.079 & 0.055 & 0.054 \\
\hline
\end{tabular}

Note: $1=332 \mathrm{~B}-22-1,97-100 \mathrm{~cm}$, spinel enclosed in olivine in glomerophyric basalt; $2=332 \mathrm{~B}-25-4,51-53 \mathrm{~cm}$, spinel enclosed in olivine in sparsely phyric basalt; $3=332 \mathrm{~B}-29-1,69-72 \mathrm{~cm}$, microphenocryst in picritic basalt; $4=332 \mathrm{~B}-29-2,9-12 \mathrm{~cm}$, core of microphenocryst in picrite; $5=332 \mathrm{~B}-$ $29-2,9-12 \mathrm{~cm}$, rim of microphenocryst in picrite; $6=332 \mathrm{~B}-37-3,11-13 \mathrm{~cm}$, core of spinel microphenocryst in picrite; $7=332 \mathrm{~B}-37-3,11-13 \mathrm{~cm}$, rim of microphenocryst; $8=332 \mathrm{~B}-36-2,3-12 \mathrm{~cm}$, spinel enclosed in plagioclase phyric basalt; $9=332 \mathrm{~B}-36-2,81-83 \mathrm{~cm}$, core of spinel partly en closed in plagioclase phenocryst; $10=332 \mathrm{~B}-36-2,81-83 \mathrm{~cm}$, rim of same spinel; $11=334-22-2,52-55 \mathrm{~cm}$, center of large spinel in peridotite; $12=334-22-2,85-87 \mathrm{~cm}$, spinel enclosed in clinopyroxene in serpentinized peridotite; $13=335-8-2,94-96 \mathrm{~cm}$, spinel microphenocryst in sparsely phyric basalt. All microprobe analyses were carried out on an ARL-EMX electron probe at SUNY, Stony Brook. Total Fe has been partitioned between $\mathrm{A}$ and $\mathrm{B}$ sites as $\mathrm{Fe}^{2+}$ and $\mathrm{Fe}^{3+}$ in the proportions required for stoichiometry.

which typically contain magnesiochromites with $\mathrm{Cr} /(\mathrm{Cr}+\mathrm{Al})$ of 0.4 .

\section{DISCUSSION}

The occurrence of spinels in MAR basalts from the Azores region $\left(30^{\circ}-40^{\circ} \mathrm{N}\right)$ is restricted to lavas with $\mathrm{FeO}^{*} /\left(\mathrm{FeO}^{*}+\mathrm{MgO}\right)$ ratio less than 0.575 , i.e., the least fractionated basalts (Sigurdsson and Schilling, in preparation). This relationship also holds true for basalts from Leg 37, as all the spinel-bearing lavas have $\mathrm{FeO}^{*} /\left(\mathrm{FeO}^{*}+\mathrm{MgO}\right)$ ratio less than 0.55 , whereas spinel-free Leg 37 basalts range from 0.54 to 0.60 . Removal of spinel by gravitative settling, either as solitary microphenocrysts or as inclusions in olivine phenocrysts, is thus clearly an important process in ocean-ridge basaltic magmas.

Most of the spinel-bearing basalts of Leg 37 studied are either olivine-cumulate types (picrites) or plagioclase-phyric (Table 2). Excluding the highly zoned spinels of the plagioclase-phyric basalts (analyses 13 and 14 in Table 1), our data suggest some systematic relations between spinel chemistry and rock composition. If spinel core compositions alone are considered, there is a decrease in $\mathrm{Mg} /\left(\mathrm{Mg}+\mathrm{Fe}^{2+}\right)$ and $\mathrm{Cr} /(\mathrm{Cr}+$ $\mathrm{Al})$ of spinels with increasing $\mathrm{FeO}^{*} /\left(\mathrm{FeO}^{*}+\mathrm{MgO}\right)$ of the lavas. Such a relation is to be expected, as the more fractionated basalts will crystallize relatively ironenriched spinels $\left(\mathrm{Mg} /\left(\mathrm{Mg}+\mathrm{Fe}^{2+}\right)=0.62-0.68\right)$. The $\mathrm{Cr} /(\mathrm{Cr}+\mathrm{Al})$ ratio of spinels is similarly related to bulk $\mathrm{Al}$ content of the rock, as discussed later.
The compositions of coexisting olivine-spinel pairs in Leg 37 rocks are plotted in Figure 4. The basalts plot within the general olivine-spinel field of MAR basalts from 29 to $40^{\circ} \mathrm{N}$ (Sigurdsson and Schilling, in preparation), and the good correlation between associated olivine and spinel is believed to be indicative of an equilibrium assemblage. A sparsely olivine-phyric basalt $(335-8-2,94-96 \mathrm{~cm})$ is, however, an exception to this trend (point $\mathrm{A}$ in Figure 4). The solitary rounded spinel grain $\left(\mathrm{Mg} /\left(\mathrm{Mg}+\mathrm{Fe}^{2+}=0.74\right)\right.$ analyzed in this rock probably represents a xenocryst which does not bear an equilibrium relation to olivine microphenocrysts of the basalt. Olivine-spinel pairs from the peridotites at Site 334 plot in a region quite separate from the basalts (B in Figure 4) reflecting the relatively high $\mathrm{Fe}$ content of the chromites. The peridotites are associated with gabbros with orthocumulate texture at Site 334, and the possibility must by considered that we are dealing with a layered sequence of ultrabasic and basic rocks, representing crystal cumulates from an MAR-type basaltic magma rather than an equilibrium assemblage. The occurrence of chromites, instead of the more typical magnesiochromites in MAR basalts, would at first sight seem to contradict such an origin for the peridotites. Magnesiochromites in some Leg 37 lavas are, however, found to be zoned to chromite margins such as in the picrites (332B-29-2, 9-12 cm). Thus, the accumulation of spinels from a slightly fractionated basaltic melt, combined with subsolidus reactions in the peridotite could conceivably account for these differences in 

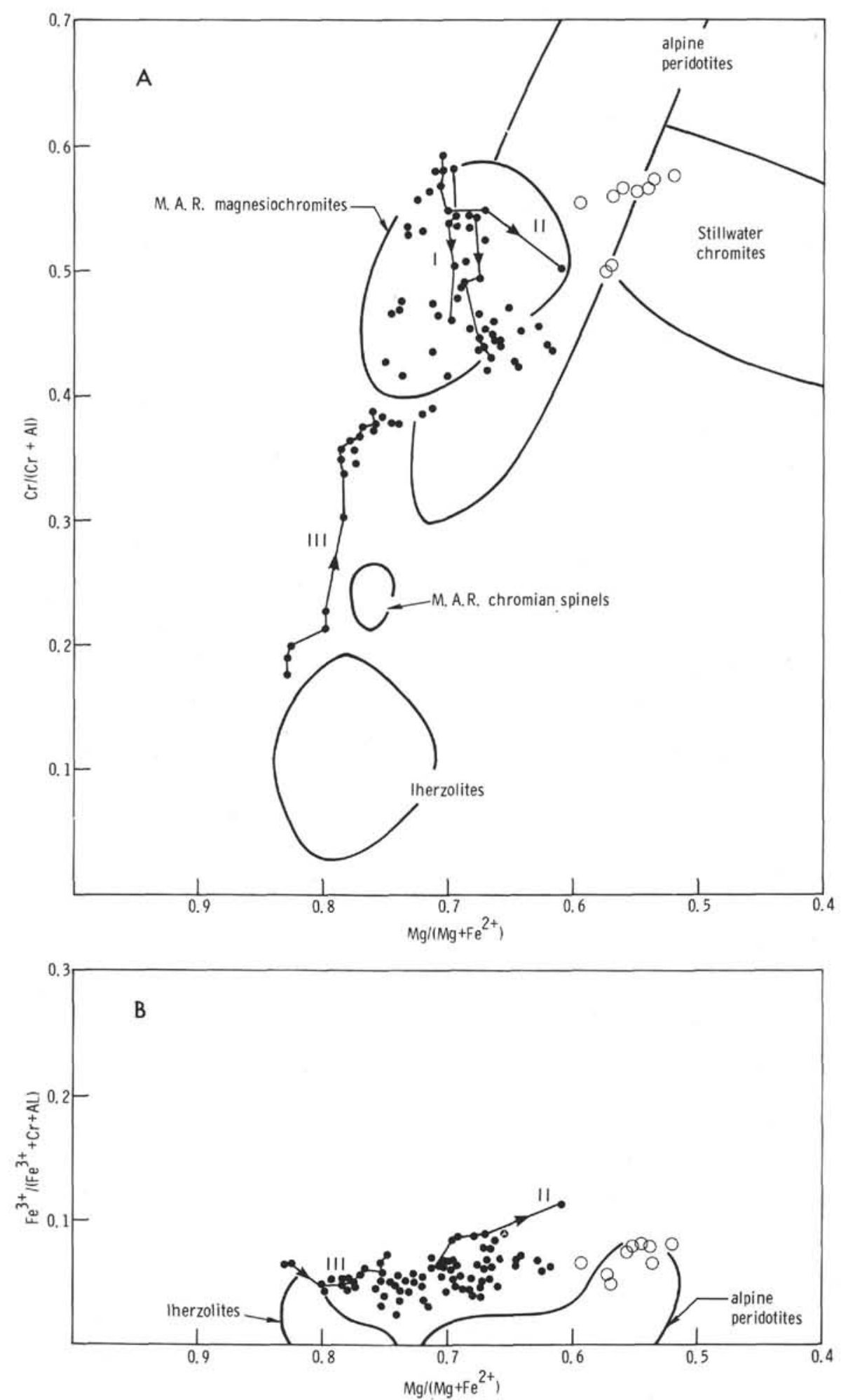

Figure 1. Compositions of Leg 37 spinels plotted in two projections of the spinel prism. Spinels from lavas shown by filled circles; spinels from peridotite at Site 334 shown by open circles. Roman numerals I, II, and III refer to zoning of the "normal" type (332B-37-3, 11-13cm), "chromite" zoning (332B-29-2, 9-12cm), and "reverse" zoning $(332 \mathrm{~B}-36-2,81-83 \mathrm{~cm})$, respectively. The compositional fields of magnesiochromites and chromian spinels from basalts of the MAR between $29^{\circ}$ and $40^{\circ} \mathrm{N}$ are from Sigurdsson and Schilling (in preparation). Also indicated are the compositions of spinels in I herzolites /O'Hara et al., 1971; Littlejohn and Greenwood, 1974), in alpine-type peridotites (Loney et al., 1971), and Stillwater chromites (Jackson, 1969). 

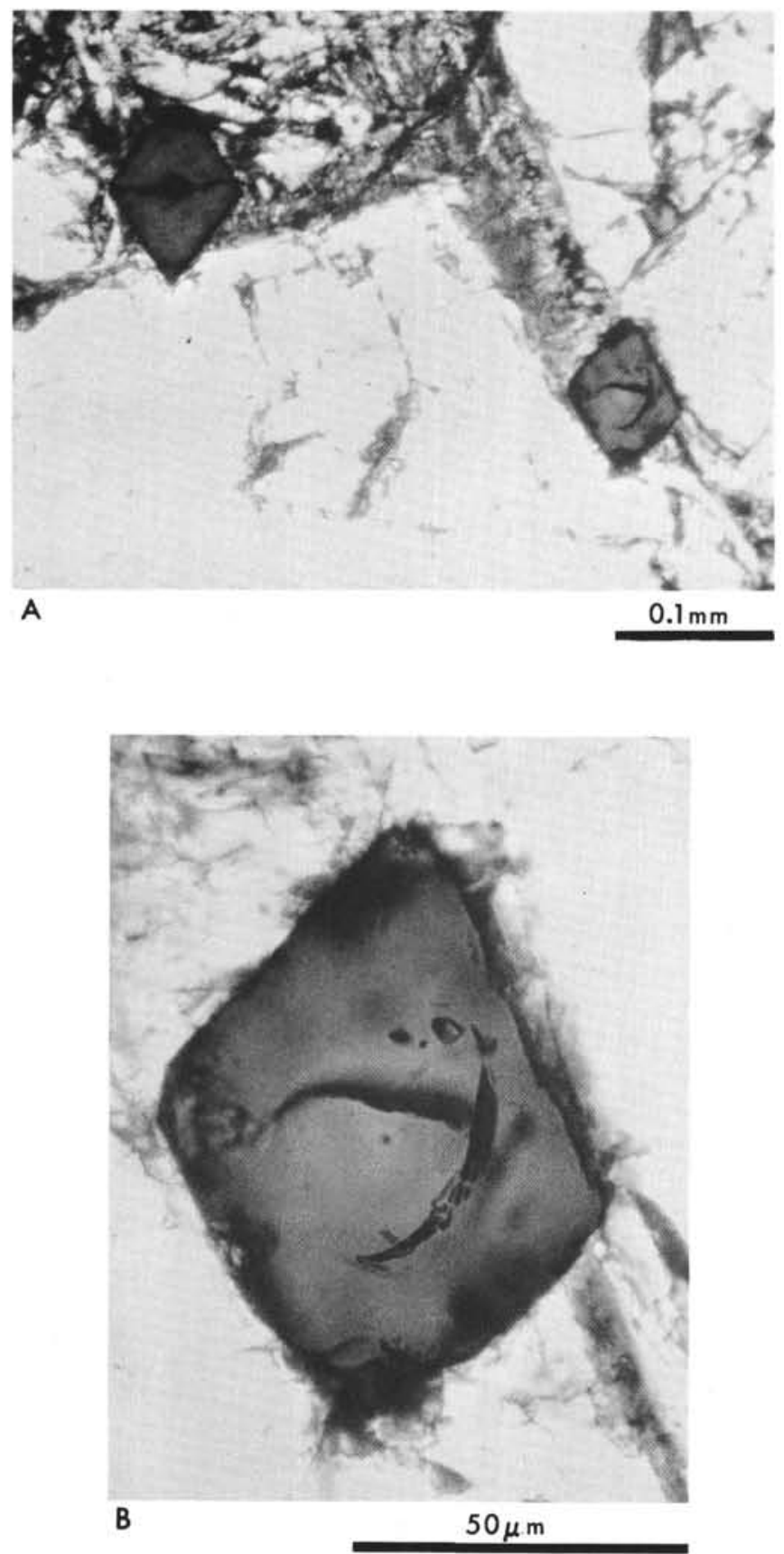

Figure 2. Photomicrographs of amber chromian spinels in plagioclase-phyric basalt 332B-36-2, $81-83 \mathrm{~cm}$. (a) Shows two zoned euhedral chromian spinels attached to plagioclase phenocrysts (An90 cores to An 78 mol \% rims). (b) Gives a closer view of a zoned spinel, indicating the compositional traverse plotted in Figure 3.

spinel chemistry. Dissimiliarities in the olivine-spinel compositional relations between basalts and peridotites can, alternatively, be viewed as a function of equilibrium crystallization temperatures (Jackson, 1969).

Factors most likely to determine the composition of spinels crystallizing from a basaltic melt are: fugacity of oxygen, temperature and pressure, bulk composition, and, in particular, the $\mathrm{Cr}$ and $\mathrm{Al}$ content of the melt.
Spinel crystallization is clearly dependent to some extent on the chromium content of the melt as illustrated by the data on MAR basalts from $29^{\circ}$ to $40^{\circ} \mathrm{N}$ (Sigurdsson and Schilling, in preparation), where spinels are generally absent from lavas with less than $400 \mathrm{ppm}$ Cr. Chromium concentrations in the spinelbearing basalts of Leg 37 are reported by Schilling (this volume, Table 1). Bulk $\mathrm{Cr}$ concentration ranges up to $1500 \mathrm{ppm}$ in the picrites, but the lowest $\mathrm{Cr}$ value for a spinel-bearing lava is $345 \mathrm{ppm}$. A consistent relationship between $\mathrm{Al}$ content of liquidus spinels and the Al content of enclosing rock has been previously noted for MAR lavas (Sigurdsson and Schilling, in preparation). Data from a variety of sources are compiled in Figure 5, illustrating the compositional dependence of spinels on $\mathrm{Al}_{2} \mathrm{O}_{3}$ content of magma. The relationship holds well in the case of glassy or variolitic and sparsely phyric basalts, where whole-rock composition approximates magma composition. Most Leg 37 lavas do not, however, conform to this trend (triangles in Figure 5) because of their porphyritic or cumulate nature.

High-alumina chromian spinels in MAR picrites from $33^{\circ} \mathrm{N}$ (point $\mathrm{C}$ in Figure 5) and in Leg 37 plagioclase-phyric basalts (332B-36-2, $81-83 \mathrm{~cm}$ ) deviate significantly from the typical magnesiochromite composition of spinels in MAR lavas. It is suggested that these aluminous spinels crystallized at high pressures in the upper mantle. This suggestion is supported by the evidence from spinel lherzolites, which typically contain spinels with $\mathrm{Cr} /(\mathrm{Cr}+\mathrm{Al})$ of $0.1-0.3$ (O'Hara et al., 1971; Eggler and McCallum, 1974), and the experimental evidence from lunar basalts: Green et al (1971) have, for example, noted that spinels on or near the liquidus show a sensitive increase in $\mathrm{Al}_{2} \mathrm{O}_{3}$ with increasing pressure. Alternatively, the high-alumina spinels in MAR lavas can conceivably be accounted for by low-pressure crystallization from an unusually $\mathrm{Al}_{2} \mathrm{O}_{3}$-rich melt $\left(>20 \% \mathrm{Al}_{2} \mathrm{O}_{3}\right)$. The lack of occurrence of such high-Al melts in tíse oceanic crust, however, renders this alternative less likely.

\section{CONCLUSIONS}

1. Minute reddish-brown spinel octahedra are common inclusions in olivines and, more rarely, in plagioclase phenocrysts in a variety of MAR basalts. The vast majority of spinels in Leg 37 lavas and in MAR lavas from $29^{\circ}$ to $40^{\circ} \mathrm{N}$ are magnesiochromites with a relatively restricted compositional range: with $\mathrm{Mg} /\left(\mathrm{Mg}+\mathrm{Fe}^{2+}\right)$ of 0.61 to 0.75 and $\mathrm{Cr} /(\mathrm{Cr}+\mathrm{Al})$ of 0.40 to 0.59 .

2. High-alumina chromian spinels with $\mathrm{Mg} /(\mathrm{Mg}+$ $\left.\mathrm{Fe}^{2+}\right) 0.75$ to 0.83 and $\mathrm{Cr} /(\mathrm{Cr}+\mathrm{Al})$ of 0.17 to 0.25 have been discovered in one lava from Hole 332B, and comparable spinels have been described from MAR lavas from $33^{\circ} \mathrm{N}$. It is suggested that these spinels owe their high-Al composition to crystallization at high pressure.

3 . Three types of zoning have been observed in spinels from Leg 37 lavas: "normal" zoning, involving decrease in $\mathrm{Cr} /(\mathrm{Cr}+\mathrm{Al})$ from core to rim, is characteristic of many magnesiochromites and occurs with little or no change in $\mathrm{Mg} /\left(\mathrm{Mg}+\mathrm{Fe}^{2+}\right)$. A second type of spinel zoning is termed "chromite" zoning and 
H. SIGURDSSON

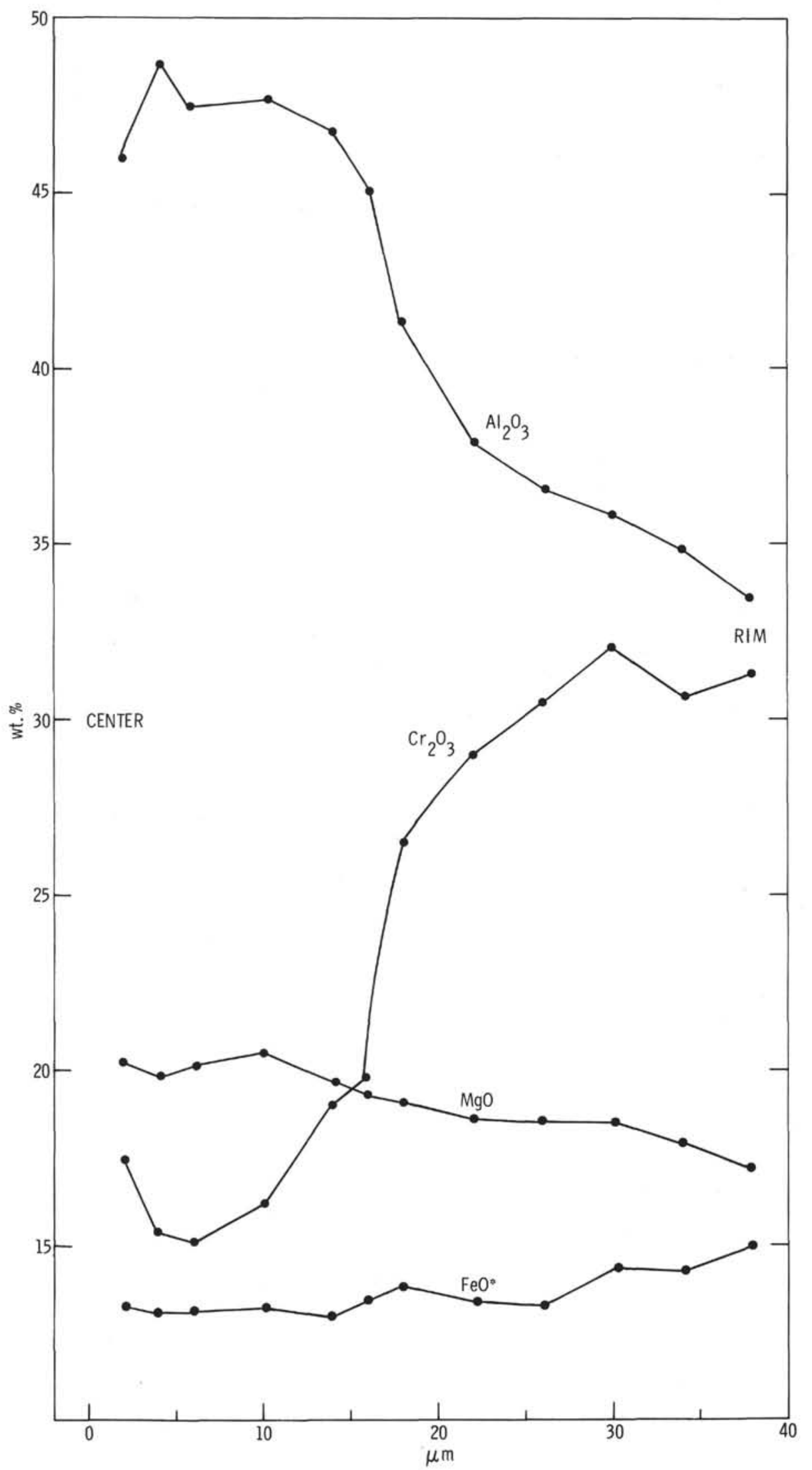

Figure 3. Compositional traverse of highly zoned chromian spinel grain in 332B-36-2, 81-83cm illustrated in Figure 2. 


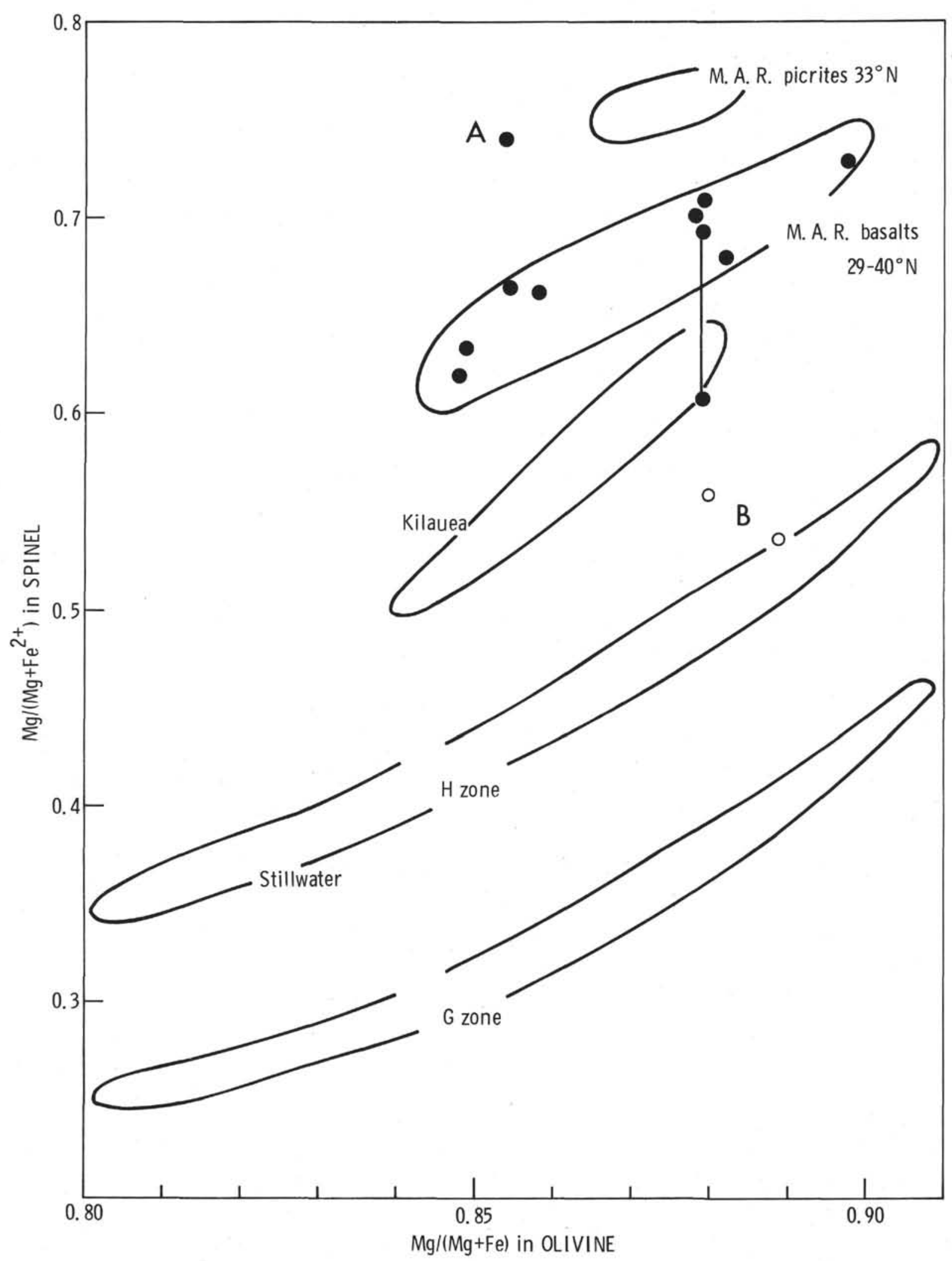

Figure 4. Olivine-spinel relationships in Leg 37 rocks. Each plotted point refers to an olivine crystal and enclosed or attached spinel grain. Solid circles: Leg 37 lavas; open circles (b): peridotites. The fields of olivine-spinel pairs in MAR basalts and picrites are after Sigurdsson and Schilling (in preparation), Kilauea data after Evans and Wright (1972), and Stillwater data after Jackson (1969). 


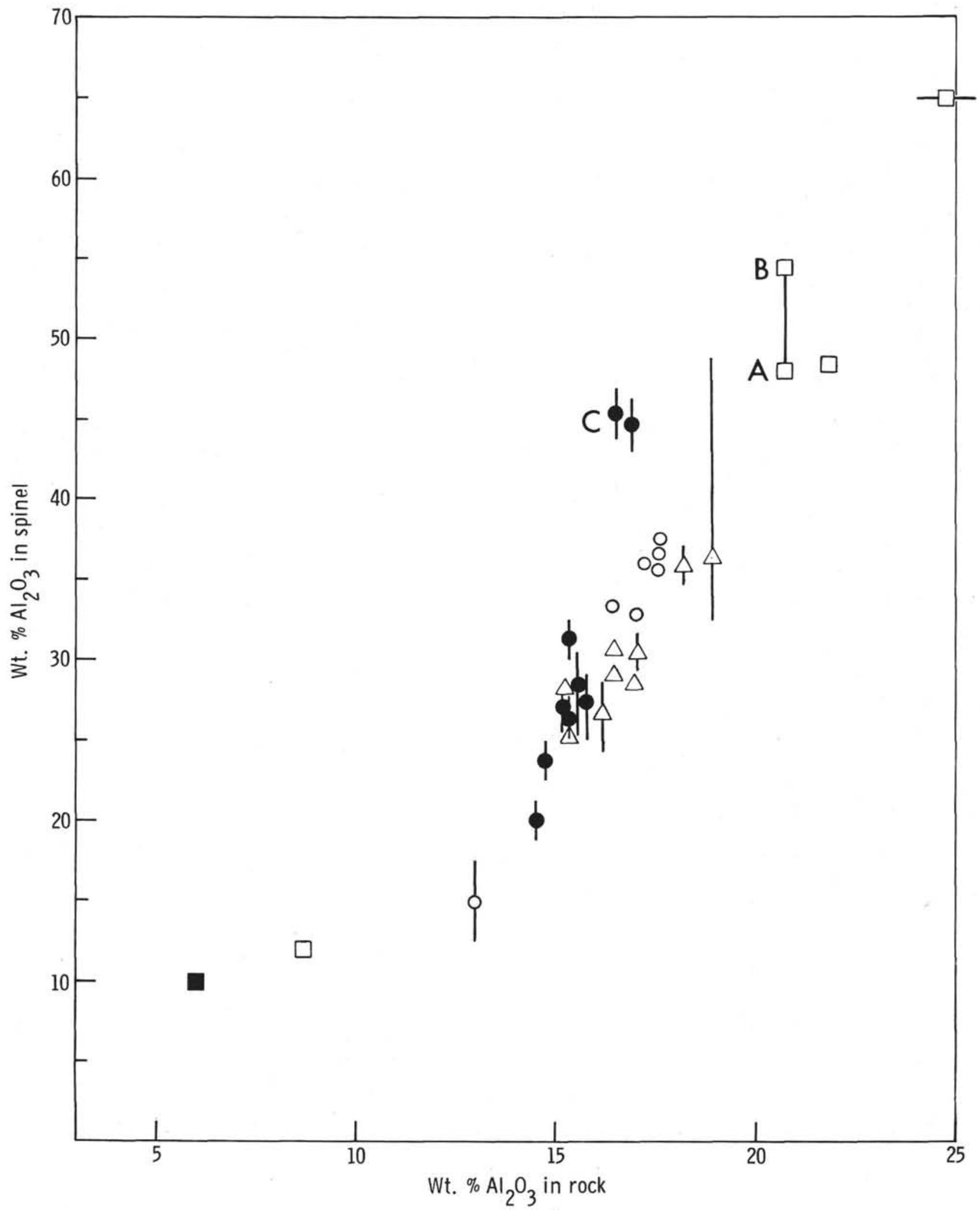

Figure 5. Wt $\% \mathrm{Al}_{2} \mathrm{O}_{3}$ in spinel versus wt $\% \mathrm{Al}_{2} \mathrm{O}_{3}$ in rock for MAR basalts (filled circles; Sigurdsson and Schilling, in preparation), Leg 37 lavas (triangles), other terrestrial basalts (open circles; Hill and Roeder, 1974; Frey et al., 1974; Ridley et al., 1974; Liou, 1974), in lunar rocks (open squares; Green et al., 1971; Cameron et al., 1973; Kushiro, 1972;), and in synthetic pyrolite (Green, 1973). Squares A and B are liquidus spinels crystallized from Apollo 14 rock at 5 and $7 \mathrm{~kb}$, respectively (Green et al., 1972). Points at $C$ mark the composition of spinels in picrite lavas from $33^{\circ} \mathrm{N}$ (Sigurdsson and Schilling, in preparation). 
is characterized by decreasing $\mathrm{Mg} /\left(\mathrm{Mg}+\mathrm{Fe}^{2+}\right)$ and increasing $\mathrm{Fe}^{3+} /\left(\mathrm{Fe}^{3+}+\mathrm{Cr}+\mathrm{Al}\right)$ from magnesiochromite cores to chromite rims. Zoning of the third type is referred to as "reverse" zoning and is only observed in chromian spinels, where a major increase in $\mathrm{Cr} /(\mathrm{Cr}+\mathrm{Al})$ and decrease in $\mathrm{Mg} /(\mathrm{Mg}+$ $\mathrm{Fe}^{2+}$ ) is observed from core to rim.

4. Spinels are restricted in occurrence to relatively unfractionated rocks, with $\mathrm{FeO}^{*} /\left(\mathrm{FeO}^{*}+\mathrm{MgO}\right)$ of 0.55 or less, and containing over $300 \mathrm{ppm} \mathrm{Cr}$.

5. Compilation of data from a variety of sources reveals a close positive relationship between $\mathrm{Al}_{2} \mathrm{O}_{3}$ concentration of melt and $\mathrm{Al}_{2} \mathrm{O}_{3}$ content of associated spinels. The available data indicate a linear relation for liquid/spinel partitioning of $\mathrm{Al}_{2} \mathrm{O}_{3}$, but major deviations from this trend (e.g., high-Al spinels, Figure 5) are most probably indicative of crystallization of spinel at high pressures.

\section{REFERENCES}

Aoki, K. and Prinz, M., 1974. Chromian spinels in lherzolite inclusions from Itinome-gata: Japan. Contrib. Mineral. Petrol., v. 46, p. 249-256.

Bence, A.E. and Albee, A.L., 1968. Empirical correction factors for the electron microanalysis of silicates and oxides: J. Geol., v. 76, p. 382-403.

Cameron, K.L., Papike, J.J., Bence, A.E., and Sueno, S., 1973. Petrology of fine-grained rock fragments and petrologic implications of single crystals from Luna 20 soil: Geochim. Cosmochim. Acta, v. 37, p. 775-793.

Dickey, J.S. and Yoder, H.S., 1972. Partitioning of chromium and aluminum between clinopyroxene and spinel: Ann. Rept. Director Geophys. Lab. Yearbook 71, p. 384-392.

Eggler, D.H. and McCallum, M.E., 1974. Xenoliths in diatremes of the Western United States: Ann. Rept. Director Geophys. Lab. Yearbook 73, p. 294-300.

Evans, B.W. and Wright, T.L., 1972. Composition of liquidus chromite from the 1959 (Kilauea Iki) and 1965 (Makaopuki) eruptions of Kilauea Volcano, Hawaii: Am. Mineral., v. 57, p. 217-230.

Finger, L.W., 1972. The uncertainty in the calculated ferric iron content of a microprobe analysis: Ann. Rept. Director Geophys. Lab. Yearbook 71, p. 600-603.
Frey, F.A., Bryan, W.B., and Thompson, G., 1974. Atlantic Ocean floor: geochemistry and petrology of basalts from Legs 2 and 3 of the Deep Sea Drilling Project: J. Geophys. Res., v. 79, p. 5507-5527.

Green, D.H., 1973. Experimental melting studies on a model upper mantle composition at high pressures under watersaturated conditions: Earth Planet. Sci. Lett., v. 19, p. $37-$ 53.

Green, D.H., Ware, N.G., Hibberson, W.O., and Major, A., 1971. Experimental petrology of Apollo 12 basalts: Part 1, sample 12009: Earth Planet. Sci. Lett., v. 13, p. 85-96.

Green, D.H., Ringwood, A.E., Ware, N.G., and Hibberson, W.O., 1972. Experimental petrology and petrogenesis of Apollo 14 basalts: Third Lunar Sci Conf. Proc. Suppl. 3, Geochim. Cosmochim. Acta, v. 1, p. 197-206.

Hill, R. and Roeder, P., 1974. The crystallization of spinel from basaltic liquid as a function of oxygen fugacity: J. Geol., v. 82 , p. $709-729$.

Irvine, T.N., 1967. Chromian spinel as a petrogenetic indicator: Part 2. Petrologic applications: Canadian J. Earth Sci., v. 4, p. 71-103.

Jackson, E.D., 1969. Chemical variation in coexisting chromite and olivine in chromitite zones of the Stillwater complex: Econ. Geol. Monogr. v. 4, p. 41-71.

Kushiro, I., 1972. Melting experiment on Apollo 14 highalumina basalt: Ann. Rept. Director Geophys. Lab. Yearbook 71 , p. 472-474.

Liou, J.G., 1974. Mineralogy and chemistry of glassy basalts, Coastal Range Ophiolites, Taiwan: Geol. Soc. Am. Bull., v. 85 , p. $1-10$.

Littlejohn, A.L. and Greenwood, H.J., 1974. Lherzolite nodules in basalts from British Columbia, Canada: Canadian J. Earth Sci., v. 11, p. 1288-1308.

Loney, R.A., Himmelberg, G.R., and Coleman, R.G., 1971. Structure and petrology of the alpine-type peridotite at Burro Mountain, California, U.S.A.: J. Petrol., v. 12, p. 245-309.

O'Hara, M.J., Richardson, S.W., and Wilson, G., 1971. Garnet peridotite stability and occurrence in crust and mantle: Contrib. Mineral. Petrol., v. 32, p. 48-68.

Ridley, W.I., Rhodes, J.M., Reid, A.M., Jakes, P., Shih, C., and Bass, M.N., 1974. Basalts from Leg 6 of the DSDP: J. Petrol., v. 15 , p. 140-159.

Sigurdsson, H. and Schilling, J-G. in preparation. Compositional variation in spinels from Mid-Atlantic Ridge basalts: $29^{\circ} \mathrm{N}$ to $40^{\circ} \mathrm{N}$. 